\title{
Turkish Linguists against the West: The Origins of Linguistic Nationalism in Atatürk's Turkey
}

\section{ilker Aytürk}

To cite this article: Illker Aytürk (2004) Turkish Linguists against the West: The Origins of Linguistic Nationalism in Atatürk's Turkey, Middle Eastern Studies, 40:6, 1-25, DOI: 10.1080/0026320042000282856

To link to this article: https://doi.org/10.1080/0026320042000282856

册Published online: 08 Sep 2010.

6 Submit your article to this journal 정

Џll Article views: 665

Citing articles: 18 View citing articles 


\title{
Turkish Linguists against the West: The Origins of Linguistic Nationalism in Atatürk's Turkey
}

\author{
ILLKER AYTÜRK
}

In the transformation from the defunct Ottoman Empire to the Republic of Turkey, the official imperial language, Ottoman Turkish, represented an undesired past in the eyes of the Turkish nationalists. Just as the Ottoman Empire was an assembly of many ethnic groups, Ottoman Turkish was a conglomeration of Turkish, Arabic and Persian with some Italian, Greek, Armenian and other European elements, and was written using Arabic characters. ${ }^{1}$ Ottoman Turkish was not, therefore, palatable for the westernizing, nationalist elite, who wanted to create a nation-state for the Turks and to burn the bridges connecting the nascent republic to its Islamic, oriental predecessor. ${ }^{2}$ As part of Mustafa Kemal Atatürk's reform movement, first, the alphabet was romanized in 1928. The establishment of the Turkish Language Institute (Türk Dil Kurumu) followed in 1932. ${ }^{3}$ The task of the institute was, among other things, to 'purify' the language by ridding it of its non-Turkish components and to coin new, 'authentic' words to replace them. ${ }^{4}$

The measures taken to carry out the language reform were justified by the linguists who were identified with the Turkish Language Institute in pragmatic and utilitarian terms with but a little hint of their symbolic significance and the underlying implications for the new Turkish identity. Previously, they had stressed the need for an alphabet change because of the difficulties involved in writing an agglutinative language such as Turkish with a Semitic alphabet; it was also argued that the romanization of the alphabet would help spread elementary education throughout the country. ${ }^{5}$ Likewise, the language reform was considered a means of democratization, a process that would lead to the closing of the gap between the languages of the ruling elite and the masses. It was suggested that a standard Turkish made available through the schooling system would facilitate and eventually bring about the active participation of every citizen in the decision-making process. ${ }^{6}$ Notwithstanding this inclination toward functionalist explanations, 
many observers of the language reform have agreed upon the existence of an important symbolic component in it. ${ }^{7}$ The rejection of the Ottoman-Islamic past as well as the Islamic identity paved the way for the official adoption and promotion of a new secular identity, one that was based on the pre-Islamic glory of the Turks. The making of a national language was at the core of the republican project of identity-building that entailed the creation of nationalist citizens out of former subjects of an empire. ${ }^{8}$ The language reform in Turkey, which culminated in the Turkish Language Thesis of the 1930s, was indeed considered an extension of the Turkish History Thesis. ${ }^{9}$ Both theses put the ancient Turks on the highest pedestal possible, extolled their contribution to civilization and reminded the Western nations that they had to acknowledge the Turks as part of their family, as a nation which contributed most generously to their civilization.

When defined in these terms, the Turkish national identity was, and one has to say still is, afflicted with a certain degree of ambiguity vis-à-vis the 'west' and the European family of nations. On the one hand, the Republic of Turkey looked toward the 'west' as the only source and model of modernity, the ultimate prize that Kemal Atatürk and the republican elite coveted so much. On the other hand, an equally strong feeling of distrust toward the 'west' counterbalanced this high regard for things western that bordered on unbridled adoration. The feeling of distrust stemmed from a now jealously guarded national independence against former invaders and was also aggravated by the widespread perception of western contempt for the Orient in general and Turks in particular. Nowhere was this ambiguity toward the 'west' clearer than in the case of the Turkish linguists of 1930s. The purpose of this article is to shed some light on the activities of this small circle of nationalist linguists, to study their encounter with what they referred to as the 'racist,' 'imperialist' and 'Christian' science of philology in the west, and to analyse the unique solutions that they devised in their quest to further Turkish westernization.

It is only natural that all mass movements have utilized and continue to utilize vernacular languages. That is the only way the leaders and ideologists of such movements make sure that they reach the maximum number of potential followers. Nationalism, however, is different from other mass movements in that not only does it seek to convey its message in the vernacular for reasons of mass appeal, but it also prizes language, that is the national language, as an end in itself. National language is the embodiment of the spirit of the nation for the nationalist: its revival signals the awakening of the nation, as its decline and extinction signal the nation's death. Nineteenth century nationalists had invariably stressed the importance of the language in delimiting the borders of the nation. Sometimes it even replaced physical kinship and blood relationship in the eyes of the nationalist, since the 
language of a nation is a more observable and demonstrable criterion to distinguish its members from others. ${ }^{10}$ Therefore, reviving and reforming vernacular languages have become a marking characteristic of all nationalist movements in Europe and Asia. ${ }^{11}$

The genesis of the perception of a sacred bond between language and nation can be traced back to the impact of Johann Gottfried Herder (17441803). Herder argued that languages are not simply the media of communication. Rather, they are the storehouses of the experiences and culture of nations. The spirit of a nation is its language, he claimed, and as such it is of utmost value and has to be protected at all costs in order to guarantee the uniqueness of a nation and its national ethos. ${ }^{12}$ Herder's ideas set the standard for a good part of the nineteenth century and they were canonized especially by the German linguists. It is striking that Germanspeaking lands produced the leading scholars of language of that century and the science of linguistics occupied a most respectable niche in German academia. ${ }^{13}$ As the Herderian link between the nation and its language became almost axiomatic among German scholars, they also blended this axiom with the newly invented root-based classification of languages. This new way of classifying languages was first put forward by Friedrich von Schlegel (1772-1829) and was developed by his brother August Wilhelm von Schlegel (1767-1845) and Wilhelm von Humboldt (1767-1835). ${ }^{14}$ According to their classification, all human languages fall under three basic categories of isolating, agglutinative and inflectional languages, which correspond to ascending levels of civilization and human achievement. ${ }^{15}$ The so-called 'inflectional superiority thesis' suggested that although the capacity for language and articulation is universal, creativity in articulation is not equally distributed among human beings. The capacity of the human mind was assumed to increase in parallel to the plasticity of one's language and, thus, those nations that speak inflectional languages were considered more creative and civilized than speakers of isolating and agglutinative languages. ${ }^{16}$ The advantage of this classification was that it provided a scientific, philological framework that legitimized the presumption of the inferiority of non-IndoEuropean peoples. The science of philology came to reflect the political, military and economic superiority of Europe in the nineteenth century and comparative philology became an apparatus of conveying the self-image of European civilization. ${ }^{17}$ William Dwight Whitney, professor of Sanskrit at Yale University, provided an eloquent statement of this line of thought in 1867:

It is true. . that linguistic science, as a branch of human history, aims at universality, and finds the tongues of the humblest tribes as essential to her completeness as those of the most cultivated and gifted nations; but 
it is also true that, mindful of proportion, she passes more lightly over the one, to give her longer and more engrossed attention to the other. While the weal and woe of every individual that ever lived goes to make up the sum of human interests, with which our human nature both justifies and demands our sympathy, we cannot but linger longest and with keenest participation over the fortunes of those who have played a great part among their fellows, whose deeds and words have had a wide and deep-reaching influence. And this is, in a very marked degree, the character of the Indo-European race. ${ }^{18}$

August Schleicher, the most important figure in mid-nineteenth century comparative philology, vigorously supported the inflectional superiority thesis as well. Schleicher, a genuine representative of nineteenth-century believers in the methodological similarity of the natural and social sciences, was interested in botany and was inspired by the Linnean classificatory model in developing his genealogical tree model of languages. He, too, classified languages as isolating, agglutinative and inflectional. The novelty in Schleicher's theory was his combination of the concept of language as a creative capacity with the Darwinian principle of 'the survival of the fittest'. ${ }^{19}$ The battle for the survival of a language, hence, had been identified with the survival of the nation that spoke that language. Speakers of the, so-called, superior inflectional languages, according to this view, had displayed a greater ability and talent for survival than other nations, whose mother tongues were non-inflectional. That decisive identification shaped much of the later nationalist thought regarding the national language and Turkish nationalists were no exception.

To all intents and purposes, the various dialects of Turkish spoken by the Turkic peoples did not attract much attention in the nineteenth century. ${ }^{20} \mathrm{~A}$ small number of scholars who worked in this field were not even able to agree on two fundamental issues. First, the naming of the over-arching language family, to which the Turkic languages belonged, was a major source of disagreement. At different times and by different scholars this family was identified as Finno-Tataric, Scythian, Altaic, UralAltaic, Ugro-Japanese or Turanian. ${ }^{21}$ Among these, however, the latter achieved more recognition than the others, especially in the Englishspeaking world. Second, there was considerable doubt regarding the composition and the extensiveness of the Turanian language family. In his address to the Turanian Section of the International Congress of Orientalists in London in 1874, Sir Walter Elliot had subsumed under the Turanian category 'all the languages of Europe and Asia which are neither Semitic nor Aryan'. ${ }^{22}$ Sir Walter's definition of the Turanian family 
was contested immediately by the next speaker, Professor Hunfalvy of Hungary, who complained that 'the notion of the Turanian languages generally accepted by the linguistic literature of this country [England] is. . .ill-defined' ${ }^{23}$ Indeed, for a good part of the nineteenth century the socalled Turanian family served as a 'dumping ground for languages awaiting classification'. ${ }^{24}$

In spite of these scholarly disagreements that characterized the study of the so-called Turanian family, the agglutinative makeup of the languages, which it comprised, was accepted without any reservations. Especially the Turkic languages exemplified the premier specimen of agglutination. The contrast between the agglutinative Turanian and the inflectional Indo-European languages helped demarcate the linguistic boundaries of the 'west' vis-à-vis the neighbouring Ottoman Empire, whose official language was Ottoman Turkish. Western, specifically German and English, philologists of the nineteenth century commonly believed that the Turkish language was not a 'civilized' language or, to put it differently, it was not a language of civilization. The famous German philologist, Friedrich Max Müller (18231900), who taught at the University of Oxford for nearly half a century, publicized and disseminated this view and was representative of the general attitude toward the Turks and the Turkish language. ${ }^{25}$ Müller devoted two of his earlier books to the study of the Turanian languages. ${ }^{26}$ Having endorsed the then fashionable principle that language is the spirit of a nation, Müller proposed to divide languages into three general classes, which correspond to the isolating, agglutinative and inflectional categories. These he called 'the family languages', 'the nomad languages' and 'the state languages'. Aryan languages constituted the 'state language' category par excellence as they were languages of literary and political traditions and civilization. Even the root $a r$, from which Müller claimed the word Aryan was derived, denotes a man of soil, husbandry and settled life. ${ }^{27}$ Praising the genius of peoples speaking inflectional languages, he argued that:

This process of handing down a language through centuries without break or loss, is possible only among people whose history runs on in one main stream; and where religion, law, and poetry supply well defined borders which hem in on every side the current of language. ${ }^{28}$

It is worth mentioning that Turcology as a separate field of inquiry was not yet born in the $1850 \mathrm{~s}$ when Müller completed his two treatises on the Turanian languages and the ancient Turkic history remained by and large unknown to him and his linguist colleagues. Still, Müller identified agglutination with nomadism and referred to the Turanian and specifically Turkic languages as 'nomad languages': 
The case is widely different with the Turanian languages. ... So far as history can reach back, no lasting nucleus of society or civilization has ever been formed in these vast Turanian wildernesses. Empires were no sooner founded there than they were scattered again like the sandclouds of the desert; no laws, no songs, no stories outlived the age of their authors. ${ }^{29}$

This amounted to a claim that Turks had never been able to establish a lasting political entity, and that they did not have a civilization of their own. Furthermore, their nomadic state of existence was reflected in their language:

There was a very good reason why the Turanian languages should for a long time have remained in this second or agglutinative stage. It was felt essential that the radical portion of each word should stand out in distinct relief, and never be obscured or absorbed, as so often happens in the third or inflectional stage. ...The French $\hat{a} g e$, for instance, has lost its whole material body, and is nothing but termination. Âge in Old French was eage and edage. Edage is a corruption of the Latin cetaticum; cetaticum is a derivative of cetas; cetas an abbreviation of cevitas; cevitas is derived from cevum, and in cevum, ce only is the radical, or predicative element, the Sanskrit $\hat{a} y$ in $\hat{a} y$-us, life, which contains the germ from which these words derive their life and meaning. ...What trace of ce or ceevum, or even cevitas and cetas remains in $\hat{a g e}$ ? ...Turanian languages cannot afford such words as âge in their dictionaries. It is an indispensable requirement in a nomadic language that it [the root] should be intelligible to many. ... It requires tradition, society, and literature to maintain words and forms which can no longer be analysed at once. ${ }^{30}$

The belief that language is the reflection of the level of civilization of a nation had allowed F. Max Müller to make sweeping and biased generalizations concerning the language and the history of Turks.

It must be stated, however, that these views were not shared universally. Arthur Lumley Davids, whose earlier work on the Turkish language and history had influenced a generation of Ottoman intelligentsia, provided a more sympathetic account:

Emerging from a primitive state of society, we view them [the Turks] passing through the various gradations which mark the progressive advancement of mankind, until arriving at the highest degree of civilization that the Asiatic race has ever attained. While the accomplished Osmanlis are making rapid strides towards rivalling the 
most learned and polished of the European States, their wandering brethren in the farthest North, whose language is the only proof of their relationship, are plunged into the depths of primitive ignorance and barbarism. ${ }^{31}$

Davids at least recognized the modernizing character of Ottoman reforms in the first half of the nineteenth century and made a distinction between the Ottoman Turks and their nomadic kinsmen in Central Asia. A.H. Sayce, an Oxford linguist, complained that 'everything has tended to make the European scholar to see in an inflected language the normal type of a perfect and cultivated tongue' and attributed this sad state of affairs to the fact that 'the founders and cultivators of comparative philology were Germans, who spoke ... one of the most highly inflected languages of modern Europe' ${ }^{32}$ François Lenormant, a French scholar of the Near East, had likewise dismissed the belief that the Turanian nations were inept in art and civilization as an 'old prejudice' which owed its origin to the 'vanity and the conceited assertions of the Germanic nations'.$^{33}$ Not even Müller considered agglutination an unchanging and timeless attribute. On the contrary, nomadic peoples that 'rise to the level of civilization and political organization, ... may approach to the system of political languages [state languages]' ${ }^{34}$ This was indeed the case according to him with the most advanced members of the Turanian family, Hungarian and Finnish.

In spite of those opposing voices from within Europe, Müller had made quite an impact on the first generation of the Turkish linguists, not as a great authority on the Turkish language, which he certainly was not, but rather as the principal representative of a 'western' paradigm in philology. On the one hand, his admiration for the clarity and rationality of Turkish grammar was quoted again and again in a variety of nationalistic textbooks and pamphlets in the early republican era in order to bring a European scholar as a witness to the beauty of the Turkish language. On the other hand, the exposure to the writings of Müller and like-minded scholars led to a painful awareness, on the part of Turkish readers, of the nineteenth century western attitudes toward the Turks and their language, the most succinct expression of which can be found in Müller's work. Although historical comparative philology, as it was practised in the early nineteenth century, was falling out of fashion in the first decades of the twentieth century, leaving the field open to new vistas of linguistic inquiry, Atatürk's team of linguists remained preoccupied with correcting the slight on Turkish honour. This they did with great verve and plenty of imagination.

The Turkish reaction in the early republican era took two distinct forms. First was the attempt to blur the line distinguishing the inflectional from the agglutinative categories and to assert that Turkish is an Indo-European 
language. The second form of reaction was even more daring than the first. It aimed at establishing Turkish as the Ursprache, the original mother tongue of all human beings. The apogee of the second movement was the notorious Sun-Language Theory of 1936.

The earliest Turkish attempt to link the Turkic languages to the languages spoken by Indo-Europeans, the so-called Aryan people, dates back to 1869 . An Ottoman general, Mustafa Celaleddin Pasha (1826-75), had his important treatise, Les Turcs Anciens et Modernes, published that year by a French publishing house in Constantinople. ${ }^{35}$ This much neglected treatise is of great importance for all students of Turkish nationalism in that it contains many elements of that ideology that would attract a growing number of devotees in the following years. ${ }^{36}$ Mustafa Celaleddin was a Polish convert to Islam. He was born in Poland and educated in his native country. Apart from Polish, he was reputed to have a profound knowledge of Latin, French, German and Russian. Moreover, he was known for his artistic abilities and also for his talent for drawing maps, which later helped him secure a job in the Ottoman army as a cartographer. Like a great many intellectuals in the fateful year of 1848, Mustafa Celaleddin, who was then called Konstanty Borzecky, was inspired by nationalistic ideals as well and participated in a Polish insurrection against the Prussian occupation. After the failure of the revolt, he fled first to Paris and then sought refuge in the Ottoman lands. In Constantinople he formally converted to Islam and was given the name Mustafa Celaleddin by the şeyhülislam. There he married into a Muslim family and settled in the predominantly Muslim district of Üsküdar. All extant data about his later life as an Ottoman general, who actually fell in the battle field in Montenegro, confirm that he took his newly adopted religion and nationality very seriously. ${ }^{37}$

In his treatise Mustafa Celaleddin endeavoured first of all to refute the theories about the racial inferiority of Turks and, second, he made an effort to prove that Turks and the European peoples had hailed from the same stock. 'Other than revealing an ignorance of the languages of Asia,' he argued, 'the contemporary ethnological theory, which excludes the Turanian races from the family of the Aryans of Europe, violates the historical rights of the Turks as to their due place, as one of the principal branches of humanity. ${ }^{38}$ The Ottoman Turks, according to him, were descendants of the great Turanian family, which should be acknowledged by the Europeans as flesh of their own flesh. He proposed to replace the racial terms Indo-European, Indo-German or simply Aryan with a new one, based on the brotherhood of and racial affinity between the Turks and the Europeans. The new term was TouroArienne. Thus, Mustafa Celaleddin had been able to praise the Turanian contribution to western civilization, on the one hand, and to portray on the other the Ottoman Turkish decision to adopt the western way of life not as a 
civilizational shift, but rather as a return to their origins. Similar to the parable of the prodigal son, ${ }^{39}$ who returned to retrieve his share from his father's property, the Ottoman Turks, waylaid so far by an enchanting but essentially alien Semitic civilization, would reclaim their birthright.

It is, therefore, evident that, unfavourably located at the far end of Asia, in a land without an outlet and accessible to the tribes of the yellow race, the great Turkish nation could not easily assert its historical rights, having lost its national literature and the monuments of its past in the Arab civilization for many centuries. ${ }^{40}$

However, a birthright can only rest on the agreement of a birth certificate and Mustafa Celaleddin first had to make the case for the racial union of the Turks and the European nations.

Mustafa Celaleddin found in comparative philology an excellent tool to prove his case. He certainly was not a philologist, but he cultivated an interest in languages and philology like many other well-educated European gentlemen in the nineteenth century. A large part of his book is devoted to comparative philological analysis of Turkish and 'Aryan' languages, especially Latin. It needs to be mentioned, however, that Mustafa Celaleddin's amateur philological analyses were totally devoid of any sort of methodology acceptable to his professional contemporaries. Unacquainted as he was with the study of morphology in Indo-European and Turkic languages, Mustafa Celaleddin's comparisons relied solely on similarities in the sounds or certain syllables. In this way he was able to derive French société from Turkish söz (word), Latin domus (domicile) from dam (roof or primitive dwelling), and Latin columna (column) from kol (arm). ${ }^{41}$ These purported similarities were so blatantly unscientific that a Turkish nationalist of a later generation brushed them aside as wild speculation, while expressing sympathy for the general line of argument contained in Mustafa Celaleddin's treatise. ${ }^{42}$

It is difficult to evaluate the impact of Les Turcs Anciens et Modernes on the Ottoman Turkish elite of the late nineteenth century. The scarcity of surviving copies shows that the limited edition of 1869 probably did not reach a great number of readers. Moreover, the language of publication French - suggests a different audience. It might well be that Mustafa Celaleddin's intended readers were Europeans, to whom he wanted to prove the racial qualities of Turks, or the Christian millets of the Ottoman Empire, as Yusuf Akçura was to claim later. The concept of Touro-Arienne might have been regarded as instrumental in transferring the loyalties of the Slavic and Greek subjects, who considered themselves essentially different from their Turkish masters, to the Ottoman state. ${ }^{43}$ Regardless of Mustafa 
Celaleddin's impact on his contemporaries, one has to recognize the influence of him and his extended family on the subsequent development of Turkish nationalism in general and Turkish linguistic nationalism in particular. ${ }^{44}$ Mustafa Celaleddin's only child, Hasan Enver Celaleddin (1851-1929), was also a pasha in the Ottoman army and as interested in Turkish history and language as his father had been. He contributed articles on these topics to the Istanbul journal, Edebiyât-ı Umûmiye Mecmuası.$^{45}$ Hasan Enver Celaleddin's daughter, Münevver, was married to Samih Rifat Bey (1874-1932), the first president of the Turkish Language Institute and chief ideologue of the Turkish Language Thesis. ${ }^{46}$

After a long hiatus, the assertion that Turkish is an Indo-European language resurfaced in the newly established Republic of Turkey. This time it was one of the main points of contention in a public and intellectual debate on the future of the Turkish language and the nature of language reform. Ahmet Cevat Emre (1876-1961) emerged as one of the most important participants in that debate and focused his research on the alleged connection between Turkish and the Indo-European family approximately between 1930 and 1935. Emre was one of the very few members of the Turkish Language Institute, who cultivated an interest in linguistics from early on and acquainted himself with the contemporary scholarship in that field. Despite his lack of a formal linguistic education, Emre's keen attention to methodology and zeal to maintain a certain level of scientificity won him the respect of European Turcologists and Atatürk, as well. Emre was born in Crete in 1876 and spent his childhood amid inter-communal strife in that disputed Mediterranean island. ${ }^{47} \mathrm{He}$ attended Kuleli Military School and, then, Harbiye, the imperial military college. He was destined to join the Ottoman army with an excellent record in his studies. When Emre's revolutionary ideas were brought to the attention of his superiors, however, he was first imprisoned in the capital and then exiled to Tripoli in Libya. He managed to return to Istanbul only after the 1908 Revolution, this time formally joining the Party of Union and Progress. He published his first book on the Turkish language, Lisan-l Osmani (The Ottoman Language), a grammar book for middle schools in $1910 .{ }^{48}$ During the First World War he was appointed assistant to a German Turcologist, Friedrich Giese, who founded and assumed the first chair of Ural-Altaic languages at the Darülfünun at İstanbul. Emre studied under Giese for about three and a half years. When Giese had to resign from his post as a result of the Mudros Armistice Agreement in October 1918, which among other things brought the German presence in the Ottoman Empire to an end, Emre occupied Giese's chair for a brief period with the agreement of Ziya Gökalp and Mehmed Emin [Erişirgil]..$^{49}$ The chair was abolished by the Ottoman government as part of a de-nationalization programme following the armistice, forcing Emre to 
struggle for a living. He joined Ottoman socialists in the Soviet Union and published a revolutionary journal in the Georgian capital, Tbilisi. His campaign in the Turkish press in 1927 for the romanization of the Turkish alphabet secured him Atatürk's support in the subsequent language reform.

Ahmet Cevat Emre's opinion regarding the affinity between Turkish and Indo-European languages was subtly different from what Mustafa Celaleddin proposed more than half a century before. Emre did not merely suggest that Turkish belongs to the Indo-European language family; he insisted that an ancient Turkic language was the original Indo-European language, carried to Europe from the Eurasian steppes. Although he occasionally challenged the tripartite classification of languages,${ }^{50}$ he continued to utilize the terminology that is intrinsic to that particular classification. This was especially clear in his efforts to prove that Turkish is an inflectional language. According to Emre, the only obstacle that prevents Turkish from being reckoned as an Indo-European language is the inflection problem. Since Turkish had been considered an agglutinative language, scholars did not even attempt to compare it with inflectional, that is Indo-European and Semitic, languages. The barrier of inflection should be overcome, wrote Emre; and once this task was accomplished, comparative philological studies would eventually prove the Turkish Language Thesis. But, he added, one should not expect this accomplishment from western scholars. ${ }^{51}$

At the First Congress on Turkish Language in 1932, where the official congress programme emphasized studies on the relationship between Turkish and Indo-European languages, 'the languages of the white races' and 'other languages of Asia and Europe', Ahmet Cevat Emre attempted to compare Turkish to the Sumer language. ${ }^{52}$ It was a common theme of Turkish nationalism of this period to claim a Central Asian origin for the Sumerians and, hence, the Mesopotamian civilization. ${ }^{53}$ The Sumerians had spoken a language that was not related to the Indo-European or Semitic families; therefore, it was one of the main aims of the Turkish History and Language Theses to establish the ethnic unity of Sumerians, the inventors of writing, and Turks, a mission that promised an exalted status for the Turkish nation. Emre, too, tried to make the case for this argument at the congress and also in a pamphlet he wrote the following year, where he declared the Sumerian cuneiform a Turkish invention. ${ }^{54}$ At the second congress in 1934, however, he returned to his favourite topic, the origin of the Indo-European peoples and languages and reiterated his views that appeared in two other books he had published in the same year:

If this [the Turkish origin of the Indo-European languages] can be proven clearly, the status of our language and of our nation and race among other nations and languages will change; millions of people will 
have to renounce one of the most salient opinions implanted in their minds; the semi-religious air that surrounds the Indo-European language family, which includes European languages, will be blown away; it will be understood that those languages had sprung from an ancient Turkic language, a language that they had assumed they had nothing to do with and that they used to look down on; they will acknowledge that ancient Turkish as their ancestor and we will consider those languages our cousins; arrogance and condescension will be a thing of past. ...Languages will be classified in a new way. ...The racial problem, created by eighteenth-century imperialism and aided by nineteenth-century mysticism, will be buried like a miscarried embryo. ...We will join that great civilized family with the status of a grandfather..$^{55}$

He continued to publish along the same lines well into the 1960s, though by then he had lost much of his influence at the Turkish Language Institute.

Emre was not the only member of the institute who sought to prove the unity of Turkish and Indo-European languages. Saim Ali [Dilemre] Bey, a doctor of medicine by profession, an amateur linguist, and a key member of the institute, studied extensively the relationship between the two and spoke about it at the first congress. ${ }^{56}$ Agop Martayan [Dilaçar], a former Ottoman Armenian teaching at the University of Sofia, who was invited by Atatürk to participate in the first congress, spoke about the 'ties between Turkish, Sumerian and Indo-European languages' ${ }^{57}$ Other papers that were read at the congress by Mehmet Saffet Bey, Hakkı Nezihi Bey, Raifpaşazade Fuat [Köseraif] Bey, Abdullah Battal Bey, buttressed the same point - that Turkish should be acknowledged as the original Indo-European language or, if not, as an equal member of that family at least. ${ }^{58}$ There was a very subtle difference between their position and that of Samih Rifat, who already had Turkish crowned as the first language of all men. Emre and others did not yet dare make such an outrageous claim with such flimsy evidence, that is, until 1935, when they would all drop scientific precaution and throw themselves into the phenomenon that was the Sun-Language Theory.

Feraizcizade Mehmed Şakir (?-1911) of Bursa wrote a grammar in 1894 and presented a manuscript copy to Abdülhamid II. In the introductory remarks he claimed to have discovered that 'all names that the Almighty God had taught Adam in paradise were of the Turkish language', and that 'other languages had derived from it [Turkish]'.59 This early attempt to depict Turkish as the lingua Adamica fell on deaf ears as it probably was regarded as a sure sign of the eccentricity of the author. Enver Celaleddin's articles repeated the same view after 1908. Nevertheless, Samih Rifat, the latter's 
son-in-law, must get the credit for popularizing and spreading this view, though he did not invent it in the first place.

Samih Rifat was born into a military family in 1874 . He held several middle-ranking posts in the Ottoman bureaucracy until 1908, but was promoted after the Constitutional Revolution. He served as a district governor (mutasarrlf) between 1909 and 1912, as the under-secretary (müsteşar) of the Ministry of Interior and finally as the governor of the vilayets of Konya and Trabzon. After the First World War he joined the nationalist government in Ankara, where he worked in the Ministry of Education. He was elected a member of parliament, deputy for Çanakkale, in 1923 and held that post until his death in 1932. ${ }^{60}$

Before the war Samih Rifat had already started reading books on philology and the Turkish language, presumably influenced by his father-in-law, Enver Celaleddin Pasha, and tried to convert his friends to his own brand of linguistic nationalism. ${ }^{61}$ But the event that catapulted him to short-lived fame and years of notoriety took place in Ankara on 3 April 1922. On that day many members of the Turkish parliament, bureaucrats and intellectuals in the nationalist capital flocked to a hall in the Ministry of Education building to listen to a rather long and amusing lecture by Samih Rifat. That the Turkish language had been the most ancient language in the world and that it had provided the crucial elements for the creation of other languages constituted the central ideas of his address. Kazım Nami [Duru] Bey, who presided over the meeting, was apparently convinced by what he had heard and decided to call for a vote and declare this discovery a scientific fact. At that moment, Topçu İhsan Bey intervened. Reflecting the uneasiness among those present, he argued that the audience lacked any scientific credentials and, therefore, they could not vote and decide on matters that pertain to the science of linguistics. In the ensuing confusion, Vasıf [Çınar] Bey took Samih Rıfat to task, sarcastically, by asking him whether he could speak Chinese. On hearing the latter's negative answer, Vasif Bey concluded the meeting with the words: 'Vaziyet anlaşıld' (the matter is understood/it is all clear). ${ }^{62}$ Samih Rifat's theory invited much criticism and ridicule, even within the nationalist circles. ${ }^{63}$ Samih Rifat did, however, manage to get an extended version of his lecture published, thanks to his influential position at the Ministry of Education. This small book, Türkçede Tasrif-i Huruf Kanunlart ve Tekellümün Menşei (The Rules of the Declension of Letters in Turkish and the Origin of Speech), is by and large forgotten today, in spite of its importance for the study of Turkish nationalism and the little known riddle that it contains. ${ }^{64}$

Samih Rifat stated his aim in writing this book in the introduction: $\mathrm{He}$ wanted to prove that 'Turks are the oldest race in the world. ${ }^{65}$ His philological endeavours were a means to that end. However, he aspired to 
transform the science of linguistics in more than one way. First, he found fault with the western linguistic tradition in that it had ruled out studying the question of the origins of language and human speech. This question, a philosophical one originally, engaged a great number of thinkers, including Jean Jacques Rousseau, Johann Gottfried Herder and Adam Smith. During the emergence of linguistics as an independent branch of science at the beginning of the nineteenth century, linguists and especially historical comparative philologists distanced themselves from this question and declined to comment on as controversial a topic as this, about which no historical data survived. Samih Rifat, in attempting to restore the question of origins to the agenda of linguistics, had recourse to a dwindling number of European linguists, who were considered by their colleagues as rebels in an established tradition. He mentioned repeatedly the names of the Italian scholar Alfredo Trombetti and Albert Cuny of France in his book and later publications. The practice of praising such European mavericks, quoting these 'righteous Gentiles' in a hostile scientific tradition had characterized not only the works of Samih Rifat, but also the nationalistic literature in the Ottoman Empire and early republican Turkey. Second, Samih Rifat advocated the introduction of the methodology of psychology into linguistic studies. He remarked that classical Islamic scholars had always considered the study of language as a branch of psychology (ilmünnefs). ${ }^{66}$ Psychological insights, he believed, could help linguists discover the residues of the first language of human beings, which remained deposited in the oldest layers of each language. Third, Samih Rifat claimed to have employed a revolutionary philological principle that would necessitate the reconsideration of much of the linguistic literature. He intended to eliminate the root-based typology that had dominated western philological studies since the beginning of the nineteenth century by casting doubt on the function of the root as the smallest meaningful particle in any given word. Samih Rifat argued that western philologists had until then studied mainly the roots in the inflectional languages that had lost their original identity; this misplaced emphasis had resulted in an incorrect language typology. The beginning of meaningful articulation, according to him, should be sought not in roots, but rather, in the first sounds that human beings were able to utter, which we today represent with vowels and consonants. ${ }^{67}$ Samih Rifat's revolutionary principle was to establish a fundamental relationship between those archaic sounds and their meanings, which, he asserted, could be unearthed in the living languages through a linguistic paleontology. Naturally, his argument boiled down to a return to the biblical 'monogenesis theory', which held that all languages issued from one and the same ancestor. Only this time, the theory was thoroughly secularized, Turkish replacing in effect the divine language of the pre-Tower of Babel era. ${ }^{68}$ Turkish was the original language of human beings, 
according to Samih Rifat, as the capacity for speech was first brought to fruition in their homeland at the heart of Asia. In other words, the issue at stake was again the worth of the Turks and their place in history. 'The Aryan and Semitic roots,' he declared, 'the majority of whose principles of origins [menşei kanunlar] we find in our Turkish, will scientifically prove to us the utmost reaches of the nobility of the Turk. ${ }^{69}$ Samih Rifat's observations that appeared in print in 1922 eventually constituted the basis on which the SunLanguage Theory of 1936 would be built. It is indeed puzzling why Samih Rifat's contribution to the latter theory had never been acknowledged, neither during the heyday of the theory in 1936, nor since.

Little information is available about Samih Rifat's activities between 1922 and 1928, but after 1928 we find him as a member of Türk Tarih Heyeti (The Committee on Turkish History), a committee that prepared the official textbooks on Turkish history. ${ }^{70}$ At the First Turkish History Congress that took place in Ankara from 2 to 11 July 1932 he appeared as the deputy director of Türk Tarihi Tetkik Cemiyeti (The Society of Turkish Historical Research) and read an important paper. ${ }^{71}$ On the night of the eleventh he was invited to Çankaya, Atatürk's residence in Ankara, along with others who participated in the congress. The decision to found a parallel society for the study of the Turkish language was taken at that crucial meeting and Atatürk personally appointed Samih Rifat director of the new Türk Dili Tetkik Cemiyeti (The Society of Turkish Language Research, later Turkish Language Institute). ${ }^{72} \mathrm{He}$ convened the First Congress on Turkish Language three months later (26 September-5 October 1932) in Istanbul, presented another paper there ${ }^{73}$ and died shortly after on 3 December 1932. Atatürk, himself, sent a letter of condolence to Türk Dili Tetkik Cemiyeti and eulogized Samih Rifat as someone 'who left novel marks in the field of Turkish language with his valuable views and accurate discoveries' ${ }^{74}$

Samih Rifat's line of thought, which praised Turkish as the mother of all languages, came to be accepted with slight nuances by most of his colleagues who were affiliated with the Turkish Language Institute. This approach had a built-in tendency to denounce western scholarship on philology and linguistics as biased and condescending. Abdülkadir İnan (1889-1976), professor of Turcology and Turkish Language at the University of Ankara, told his students that Turkish scholars did acknowledge the contribution of western scholars. Yet, he added, the Turkish nation is not an object of study by the west; Turks could study themselves, as well. He further argued that European linguistic, historical, ethnographic and archaeological studies were meant to prove that Europeans are a different and superior race; that this race created a higher culture and has the right to rule the inferior races. Linguistics and other sciences, according to him, had been rendered tools in this imperialist and colonialist quest, a reflection of bigoted Christian mentality. ${ }^{75}$ 
İnan found Nikolai Yakovlevich Marr (1865-1934), the maverick Soviet linguist and founder of the now defunct Japhetidology school, very close to his heart and in his introduction to a Turkish translation of one of Marr's works, he maintained that:

Marr's important service in the field of language is his revolt against the fanaticism of the classical Indo-European school and against this school's negligence of and condescension toward languages other than those that are related to Latin, Greek and Sanskrit. 'Indo-Europeanism' in Marr's view, is a sickness that hinders the progress of science like the fanaticism of the Catholic priests in the medieval period. It is a vicious circle set by formalists, who refuse to acknowledge the share of the nations who played the greatest role in the cultural history of the world (for instance, the Turks)...[According to Marr] the blunders of the Europeans are not the fault of every single scientist; it is predetermined by the ideology and the principles of the school that they belong to. It is not enough to present evidence that disproves these blunders. It is necessary to demolish the school to its foundations and to establish a new school in place of it. ${ }^{76}$

Tahsin Mayatepek, a Turkish diplomat in Mexico City, prepared lists of words in Central and South American languages that, he thought, derived from a Turkic ancestor and presented his findings at the Second Congress on Turkish Language in $1934 .{ }^{77}$ Saim Ali Dilemre read a paper at the second congress on the political considerations that shaped the linguistic research and complained about racism (rasistlik) intrinsic to those studies. ${ }^{78}$

The rudiment of the Sun-Language Theory appeared in this environment in the last months of 1935 and the theory was proclaimed in its final form in 1936, receiving the blessing and active support of the Turkish government at the Third Turkish Language Congress in late $1936 .{ }^{79}$ To put it briefly, the Sun-Language Theory was a bewildering combination of historical comparative philology, various elements from psychological theories of the nineteenth century and psychoanalytical themes from Sigmund Freud and Carl Gustav Jung. ${ }^{80}$ The details about how the theory was concocted in the first place are not exactly clear, but apparently it was the brainchild of the same circle of amateur linguists, most of whom were members of the Turkish Language Institute. In pre-historic times, the theory goes, the Turkic peoples of Central Asia had established an illustrious civilization; but as a result of climatic changes and a severe drought they started to emigrate in all directions, transmitting their Neolithic civilization to other peoples of the world.$^{81}$ Naturally, it was assumed, the ancient form of the Turkish that these conquering emigrants spoke was also carried with them and contributed to 
every primitive language the most important concepts necessary for abstract thought as loanwords. Hence, the Sun-Language Theory had provided a pseudo-scientific explanation for a presumed linguistic transplantation and complemented the equally half-baked Turkish History Thesis.

The scientific methodology of the theory, to the extent that one can consider it scientific, was to conduct etymological studies on a diverse group of languages, including Latin, Greek, Romance and the Germanic languages, Arabic, Sumerian and the native languages of North, Central and South America. All these etymological studies were undertaken with the help of a 'revolutionary' etymological method, according to which the smallest meaningful particle of each word was not a root, but a sound, a psychoanalytic unit. Similar to what Samih Rifat had suggested earlier, each sound was endowed with a particular meaning regarding the identity of the speaker, or demarcated the boundaries between the speaker and an object. The proponents of the theory tried to establish that Turkish is the language that reflects the perfect form of these sound-meaning relationships, it being the Kultursprache of the Neolithic Age. In their eyes, each such correspondence between a certain sound and meaning had originated in ancient Turkish and found its way into other languages. These correspondences were etched in the sub-consciousness of all nations and peoples. Recalling Jung's analysis of the collective sub-consciousness of humanity, the Sun-Language Theory served as a method to discover the ancient universal language, traces of which remained hidden even in the geographically remotest languages.

An interesting component of the Sun-Language Theory was the role of the sun in the birth of the language. How the sun, as a concept, found its way into the new Turkish linguistic theory and why it was chosen over other forces of nature remains a mystery that needs to be addressed by historians. It was claimed that language was born as an act of worship, as part of an ancient Turkic ritual in the cult of the sun. Those Central Asian worshippers, who wanted to salute the omnipotence of the sun and its life-giving qualities, had done so by transforming their meaningless blabbering into a coherent set of ritual utterings. The sun connection paved the way for the Sun-Language ideologues to imagine and 'prove' relationships between Turks and any other ethnic group, which worshipped the sun at some point in history. ${ }^{82}$

Fifteen prominent foreign Turcologists and experts on the Turkish language were invited to the Third Turkish Language Congress, as guests of the Turkish government, to listen to the presentations on the Sun-Language Theory and provide their opinion of it. ${ }^{83}$ They were selected as members of the Commission on the Sun-Language Theory, where their Turkish colleagues expected them to endorse the findings of the Turkish linguists. ${ }^{84}$ The end result, however, was devastating for the Turkish theory. Three of the 
foreign scholars did not participate in the commission from the start, excusing themselves for personal reasons. ${ }^{85}$ Among those who stayed, only the Soviet scholars openly supported the Sun-Language Theory, whereas others remained non-committal. They all said kind words about the recent progress of philology in Turkey, but reiterated that they had not had enough time to study the Turkish theory and reach a conclusion. On the other hand, Friedrich Giese, the former teacher of Ahmet Cevat Emre, did not mince his words:

What is the principle behind these studies? Are you depending on unambiguous proof, or are you proceeding by intuition? Although these are very interesting matters, one still needs to depend on a methodology. What is that methodology? ${ }^{86}$

The lack of sympathy for the Sun-Language Theory surprised the Turkish proponents present at the meeting. İbrahim Necmi Dilmen, general secretary of the Turkish Language Institute, said he was perplexed to see the indecision on the part of the guest scholars. ${ }^{87} \mathrm{He}$ tried to clarify the Turkish standpoint in a long speech and added:

We are proceeding according to the scientific methodology and not by intuition. Our methodology is the methodology of the (Sun-Language). Every methodology runs into difficulties first, therefore it is natural that this one is not accepted right away. But we hope that our friends will change their minds if they try to understand one another and study the problem from, what the French call, a 'large [wide]' perspective. ${ }^{88}$

Nevertheless, the damage was done and from then on international acceptance of the Sun-Language Theory was doomed to failure. It survived for a few more years as Atatürk's pastime, when he enjoyed inventing a Turkish pedigree for non-Turkish words. However, it was clear that the enthusiasm of the months that preceded the congress was no more and the Turkish Language Institute quietly dropped the theory from its agenda.

There are several conclusions to be drawn from this particular case of linguistic nationalism. First, the Turkish case illustrates the need for authenticity and search for historical legitimacy in times of rapid modernization and shift from one civilization to another. It is possible to argue that, in early republican Turkey, the History and Language Theses were employed to cope with the problems intrinsic to the process of westernization. There had always been detractors from that path since the beginning of westernization in the Ottoman Empire, on the grounds that introduction of alien ideas and institutions into the Turco-Islamic civilization would only accelerate the demise of the Ottoman polity. In this respect, an idea that was 
first put forward by Mustafa Celaleddin Pasha in 1869 to tackle that criticism culminated in a unique solution in the 1930s - to claim that westernization is not an imitation, but rather an identification with the forgotten Turkish Golden Age. This was, indeed, the return of the penitent prodigal son; it amounted to recovering what was rightfully the heritage of the Turks and parting with the habits and traditions of the past. Turks should be acknowledged as part of the west in linguistic and historical terms, which, it was hoped, would pave the way for modern Turkey's full accession to European civilization. The studies of Turkish linguists and historians were therefore meant to undercut the decades-old challenge posed by the conservative critics of westernization. Second, the linguistic theories of the 1920 s and 1930s were also essential components of the nation-building programme in Turkey, one that aimed at providing the nation with a past that it can be proud of. One whole generation was educated at Turkish schools according to the precepts of the Turkish History and Language Theses. The theses instilled in them an awareness of belonging to a great nation, which carried its civilization to the west and whose latest political manifestation was the Republic of Turkey. Third, the appearance of ethnicity and race based terminology in the linguistic writings of that period does not in any way indicate the wholesale conversion of an academic elite to the racist ideology. Rather than being the result of a profound change of mentality, the use of that terminology was an attempt to neutralize the racist condemnation of the Turks from within by utilizing the same jargon. Fourth, the encounter between the Turkish linguists and the so-called 'western' or 'Indo-European' linguistics demonstrates that language reform in Turkey stood for more than its functional utility in creating a more democratic society by bridging the gap between the languages of the elite and the masses. The Turkish language possessed a symbolic value in the eyes of the Turkish nationalists in that proving its worth, beauty and antiquity was a matter of national pride. Lastly, this case study of linguistic nationalism in early republican Turkey exposes a certain weakness of contemporary nationalism studies regarding the question of national languages. The academically fashionable approach to linguistic nationalism is a functionalist one, which reduces this phenomenon to a mere ideological façade. ${ }^{89}$ The nationalistic interest in language is portrayed as a symptom of deeper social forces in industrial societies that favour the creation of a monolingual national labour force out of a multi-ethnic, multi-lingual society. This approach, however, neglects the symbolic value of the mother tongue for the nationalist. It leaves out the human aspect and the emotions, desires and anxieties of an individual. Turkish language reform provides enough evidence to reconsider some aspects of the functionalist approach. 


\section{NOTES}

Earlier versions of this article were presented at 'Manifestations of National Identity in Europe' Conference (18-20 May 2001, Minneapolis) and the Fourth European Social Science History Conference (27 Feb.-2 March 2002, The Hague). I would like to thank Professors Avigdor Levy and Jacob Landau for their comments and suggestions. Zana Çitak has kindly read all previous versions and undertaken the French translations.

1. Fahir İz, 'Ottoman and Turkish', in Donald P. Little (ed.), Essays on Islamic Civilization: Presented to Niyazi Berkes (Leiden: E.J. Brill, 1976), pp.118-39.

2. For the origins of Turkish linguistic nationalism in the Ottoman Empire, see David Kushner, The Rise of Turkish Nationalism 1876-1908 (London: Frank Cass, 1977), pp.56-80 and 906; Yusuf Ziya Öksüz, Türkçe'nin Sadeleşme Tarihi: Genç Kalemler ve Yeni Lisan Hareketi (Ankara: Türk Dil Kurumu Yayınları, 1995). On the history and various aspects of the language reform in Turkey, see Uriel Heyd, Language Reform in Modern Turkey (Jerusalem: The Israel Oriental Society, 1954); Karl Steuerwald, Untersuchungen zur Türkischen Sprache der Gegenwart: Die Türkische Sprachpolitik seit 1928 (Berlin-Schöneberg: Langenscheidt, 1963); Geoffrey Lewis, The Turkish Language Reform: A Catastrophic Success (Oxford and New York: Oxford University Press, 1999); Jens Peter Laut, Das Türkische als Ursprache: Sprachwissenschaftliche Theorien in der Zeit des erwachenden türkischen Nationalismus (Wiesbaden: Harrassowitz, 2000); Jacob M. Landau, 'Language Policy and Political Development in Israel and Turkey', in Brian Weinstein (ed.), Language Policy and Political Development (Norwood, NJ: Ablex, 1990), pp.133-49; Jacob M. Landau, 'The Role of Language in the National Movements in Turkey and Israel', Cahiers d'Études sur la Méditerranée Orientale et le Monde Turco-Iranien, No.28 (June-Dec. 1999), pp.41-9. The most authoritative account in Turkish is Agah Sirrı Levend, Türk Dilinde Gelişme ve Sadeleşme Evreleri, 3rd printing (Ankara: Ankara Üniversitesi Basımevi, 1972). Also see Zeynep Korkmaz, Türk Dilinin Tarihi Akışı İçinde Atatürk ve Dil Devrimi (Ankara: Ankara Üniversitesi Basımevi, 1963); Kamile İmer, Dilde Değişme ve Gelişme Açısından Türk Dil Devrimi (Ankara: Ankara Üniversitesi Basımevi, 1976); Kamile İmer, Türkiye'de Dil Planlaması: Türk Dil Devrimi (Ankara: T.C. Kültür Bakanlığı Yayınları, 1998).

3. The original name of the institute was 'Türk Dili Tetkik Cemiyeti' (The Society of Turkish Language Research).

4. The official aim of the institute was 'to bring to light the beauty and the richness of the Turkish language and to elevate it to the height that befits its value among the languages of the world'. Türk Dili Tetkik Cemiyeti Nizamnamesi (İstanbul: Devlet Matbaası, 1932), p.3. The vagueness of the statute contrasts sharply with the institute's unmistakable Turkification policy in those years. The extant protocols of the central committee of the institute confirm this preoccupation with linguistic nationalism. The majority of the 111 meetings recorded in the protocol book dealt with the issue of coining proper Turkic equivalents for Arabic and Persian elements in Turkish. See Türk Dili Tetkik Cemiyeti 1933 Yllı Zabit Defteri, unpublished manuscript, Archive of the Turkish Language Institute, Ankara.

5. A thorough discussion of the alphabet reform can be found in Bilal N. Şimşir, Türk Yazı Devrimi (Ankara: Türk Tarih Kurumu Basımevi, 1992).

6. Sadri Maksudi [Arsal], Türk Dili İçin (Ankara: Türk Ocakları İlim ve Sanat Heyeti Neşriyatı, n.d. [1930]), pp.290-316.

7. Bernard Lewis, The Emergence of Modern Turkey, 2nd edn (New York: Oxford University Press, 1968), pp.425-36; Feroz Ahmad, The Making of Modern Turkey (London and New York: Routledge, 1993), pp.80-2; Erik J. Zürcher, Turkey: A Modern History, revised edn (London and New York: I.B. Tauris, 1998), pp.196-9.

8. Ahmet Yıldız, 'Ne Mutlu Türküm Diyebilene': Türk Ulusal Kimliğinin Etno-Seküler Sinırlarl (1919-1938) (İstanbul: İletişim, 2001), pp.286-90.

9. Büşra Ersanl1-Behar, İktidar ve Tarih: Türkiye'de 'Resmi Tarih' Tezinin Oluşumu (19291938) (İstanbul: Afa, 1992); Etienne Copeaux, Türk Tarih Tezinden Türk-İslam Sentezine, trans. Ali Berktay (İstanbul: Tarih Vakfi Yurt Yayınları, 1998). On the relationship between 
the two theses, see Hasan Reşit Tankut, Dil ve Irk Münasebetleri Hakkında (n.p.); Hasan Reşit Tankut, Prehistuvara Doğru Bir Dil İzlemesi ve Güneș-Dil Teorisinin İzahı (İstanbul: Devlet Matbaas1, 1937); İbrahim Necmi Dilmen, Türk Tarih Tezinde Güneş-Dil Teorisinin Yeri ve Değeri (İstanbul: Devlet Matbaas1, 1937); Şemsettin Günaltay and Hasan Reşit Tankut, Dil ve Tarih Tezlerimiz Üzerine Gerekli Bazı İzahlar (İstanbul: Devlet Basımevi, 1938).

10. Carl Darling Buck, 'Language and the Sentiment of Nationality', The American Political Science Review, Vol.10, Feb. (1910), pp.46-7.

11. Elie Kedourie, Nationalism, 4th expanded edn (Oxford: Blackwell, 1993), pp.56-68; Joshua A. Fishman, Language and Nationalism: Two Integrative Essays (Rowley, MA: Newbury House Publishers, 1973); Maurice Olender, The Languages of Paradise: Race, Religion, and Philology in the Nineteenth Century, trans. Arthur Goldhammer (Cambridge and London: Harvard University Press, 1992); Mary Anne Perkins, Nation and Word, 1770-1850: Religious and Metaphysical Language in European National Consciousness (Aldershot: Ashgate, 1999).

12. F.M. Barnard, Herder's Social and Political Thought: from Enlightenment to Nationalism, rev. edn (Oxford: Clarendon Press, 1967); F.M.Barnard, 'National Culture and Political Legitimacy: Herder and Rousseau', Journal of the History of Ideas, Vol.44, April-June (1983), pp.231-53.

13. Philologists in other European countries or in America were mostly trained in German universities. For biographical information, see Harro Stammerjohann (ed.), Lexicon Grammaticorum: Who's Who in the History of World Linguistics (Tübingen: Max Niemeyer, 1996).

14. Anna Morpurgo Davies, 'Language Classification in the Nineteenth Century', in Thomas A. Sebeok (ed.), Current Trends in Linguistics, 13: Historiography of Linguistics (The Hague and Paris: Mouton, 1975), pp.607-716; Martin L. Manchester, The Philosophical Foundations of Humboldt's Linguistic Doctrines (Amsterdam and Philadelphia: John Benjamins Publishing Company, 1985), pp.125-42.

15. The assumption was that the three stages of language development reflected the three classes of languages. In the isolating stage, each root is independent and there is no difference between a root and a word. For instance, in Chinese, which according to these philologists was stuck at the isolating stage, there is no distinction between a noun, a verb, an adverb or a preposition. The same word-root can be used to convey the meaning of each without a conjugation. In the agglutinative stage, when two or more roots combine to form another word, or when suffixes are attached, one of the roots is radically independent while others terminate and the suffixes are declined. All Ural-Altaic languages are at this stage. In the inflectional stage, however, roots do not retain their original independence. They are constantly conjugated according to their grammatical use. This is the case with IndoEuropean and Semitic languages. See F. Max Müller, The Science of Language, Vol.1 (London: Longmans, Green, and Co., 1899), pp.391-3.

16. R.L. Brown, Wilhelm von Humboldt's Conception of Linguistic Relativity (The Hague and Paris: Mouton, 1967), pp.68-84; Manchester, The Philosophical Foundations, pp.125-42.

17. Mária Tsiapera, 'Organic Metaphor in Early 19th Century Linguistics', in Hans-Josef Niederehe et al., History and Historiography of Linguistics (Amsterdam and Philadelphia: John Benjamins Publishing Company, 1990), pp.577-87; Joan Leopold, 'Ethnic Stereotypes in Linguistics: The Case of Friedrich Max Müller (1847-51)', in Hans Aarsleff et al., Papers in the History of Linguistics (Amsterdam and Philadelphia: John Benjamins Publishing Company, 1987), pp.501-512; T. Craig Christy, 'Steinthal and the Development of Linguistic Science: The Convergence of Psychology and Linguistics', in Aarsleff et al., Papers, pp.491-9; Olender, The Languages of Paradise; Raymond Schwab, The Oriental Renaissance: Europe's Discovery of India and the East, 1680-1880, trans. Gene PattersonBlack and Victor Reinking (New York: Columbia University Press, 1984); Edward W. Said, Orientalism (New York: Vintage, 1979).

18. William Dwight Whitney, Language and the Study of Language: Twelve Lectures on the Principles of Linguistic Science (London: N. Trübner \& Co., 1867), pp.229-230. 
19. August Schleicher, Die darwinische Theorie und die Sprachwissenschaft (Weimar: Böhlau, 1873); F. Robins, A Short History of Linguistics (London: Longman, 1992), pp.202-4.

20. Holger Pedersen, Linguistic Science in the Nineteenth Century: Methods and Results, trans. John Webster Spargo (Cambridge: Harvard University Press, 1931), p.111; Karl H. Menges, The Turkic Languages and Peoples: An Introduction to Turkic Studies (Wiesbaden: Harrassowitz, 1968). For a dated and largely misconceived study, which, however, reflects the British attitude on this topic, see Geographical Section of the Naval Intelligence Division, A Manual on the Turanians and Pan-Turanianism (London: His Majesty's Stationery Office, n.d.).

21. See the remarks by Léon de Rosny in Congrès International des Orientalistes: CompteRendu de la Première Session, Paris, 1873 (Paris: Bouchard-Huzard, 1874), p.422; and T.G. Tucker, Introduction to the Natural History of Language (London: Blackie \& Son, 1908), p.129.

22. Sir Walter Elliot, 'Address', in Transactions of the Second Session of the International Congress of Orientalists, London, September 1874 (London: Trübner \& Co., 1876), p.54.

23. Professor Hunfalvy, 'On the Study of the Turanian Languages', in Transactions of the Second Session of the International Congress of Orientalists, p.64.

24. Vladimir Minorsky, 'Tûrân', The Encyclopedia of Islam, 1st edn (1913-1934).

25. E.W. Hopkins, 'Max Müller', in Thomas A. Sebeok (ed.), Portraits of Linguists, Vol.1 (Bloomington: Indiana University Press, 1966), pp.395-9; Lourens P. van den Bosch, 'Language as the Barrier between Brute and Man: Friedrich Max Müller and the Darwinian Debate on Language', Saeculum, Vol.51 (2000), pp.57-89. In general, Max Müller was not known for his admiration for Turks. In a letter to his diplomat son, who was stationed at the British embassy in İstanbul, he wrote: 'Constantinople must be a lovely place but for the unspeakable Turk... . there is no excuse for these Turanians living in Europe.' He visited İstanbul in 1893 for three months. He was received by Abdulhamid II, who showed him great respect and presented him with the Order of Mejidiye and the Order of Merit. Friedrich Max Müller, The Life and Letters of the Right Honourable Friedrich Max Müller (London and New York: Longmans, 1902), pp.308-17.

26. [Friedrich] Max Müller, Letter to Chevalier Bunsen on the Classification of the Turanian Languages (London: n.p., 1854); The Languages of the Seat of War in the East: with a Survey of the Three Families of Language, Semitic, Arian, and Turanian, 2nd edn (London: Williams and Norgate, 1855).

27. Müller, Letter to Chevalier Bunsen, pp.21-2. On Müller's contribution to the Arian ideology of the nineteenth and twentieth centuries, see George L. Mosse, Toward the Final Solution: A History of European Racism (New York: Harper Colophon Books, 1980), pp.42-4.

28. Müller, The Languages of the Seat of War, pp.86-7.

29. Ibid., pp.87-8.

30. F. Max Müller, The Science of Language, p.402; also see Languages of the Seat of War, p.91.

31. Arthur Lumley Davids, A Grammar of the Turkish Language: with a Preliminary Discourse on the Language and Literature of the Turkish Nations (London: Parbury \& Allen, 1832), p.ii.

32. A.H. Sayce, Introduction to the Science of Language, Vol.2 (London: C. Kegan Paul \& Co., 1880), pp.66-7.

33. Quoted in Sayce, Introduction, p.188.

34. Max Müller, The Languages of the Seat of War, p.94.

35. Moustapha Djelaleddin, Les Turcs Anciens et Modernes (Constantinople: Imprimerie du 'Courrier d'Orient', 1869). Bibliothèque Nationale in Paris has another title by the same author. It seems that Mustafa Celaleddin wanted to have the final third of his former book published as a separate volume and made many corrections to it. This edition did not apparently take place and the only copy with the author's autograph notes on it can be consulted in that library. See Moustapha Djelaleddin, L'Europe et le Touro-Aryanisme, n.p. Another comparison of the Turkish language with European languages was undertaken a few years later by Louis Charrel, a teacher at the Mekteb-i Sultani (Lycée Galatasaray). See Louis Charrel, Études Philologiques sur la Langue Turque (Constantinople: Imprimerie de l'Orient Illustré, 1873). 
36. Yusuf Akçura, Yeni Türk Devletinin Öncüleri: 1928 Yllı Yazıları (Ankara: T.C. Kültür Bakanlığ 1,2001$),$ p.23.

37. Ibid., pp.27-9; Jerzy S. Łatka, Lehistan'dan Gelen Şehit: Mustafa Celaleddin Paşa/ Konstanty Borzecky (İstanbul: Boyut, 1987); and also see his son Hasan Enver Celaleddin Pasha's letter about his father, 'Oğlum Samih Bey'e', Tarih ve Toplum Vol.1, No:1 (1984), pp. 5-14.

38. 'La théorie ethnologique du jour qui exclut les races touraniennes de la famille des Aryas de l'Europe outre qu'elle dénote l'ignorance des langues de l'Asie, fait tort aux droits historiques des Turcs à la place leur due, parmi les principales branches de l'humanité.' Autograph correction. Moustapha Djelaleddin, L'Europe, p.229.

39. Luke 15:11-32.

40. 'Il est donc évident que, placée désavantageusement au fond de l'Asie, dans un pays sans débouches et à la portée des tribus de la race jaune, la grande nation turque, ayant perdu depuis plusieurs siècles, dans la civilisation arabe, son écriture nationale et les monuments de son passé, ne peut facilement revendiquer ses droits historiques.' Moustapha Djelaleddin, L'Europe, p.233.

41. Ibid., pp. 252-4. There are dozens of other examples.

42. Akçura, Yeni Türk Devletinin Öncüleri, p.25.

43. Ibid., pp.24-5.

44. According to Şerafettin Turan, Mustafa Celaleddin was one of the most popular authors among the Young Turks in the early 1900s and had an impact on Atatürk as well. See his, Atatürk'ün Düşünce Yapısını Etkileyen Olaylar, Düşünürler, Kitaplar, 3rd impression (Ankara: Türk Tarih Kurumu Basımevi, 1999), p.25.

45. See Enver Celalettin Pasha's biography in his letter, 'Oğlum Samih Bey'e', p.6.

46. Another daughter, Ayşe Celile, was the mother of the Turkish poet, Nazım Hikmet.

47. The following biographical details are from Ahmet Cevat Emre's important memoir, Iki Neslin Tarihi: Mustafa Kemal Neler Yaptı (İstanbul: Hilmi Kitabevi, 1960).

48. Ahmet Cevat [Emre], Lisan-l Osmani: Sarf ve Nahiv (İstanbul: Kitabhane-i Askeriye, 1910).

49. Emre, İki Neslin Tarihi, pp.220-2.

50. Ahmet Cevat [Emre], Türkçe ve Hint-Avrupa Dilleri: 'Türk Tarihinin Ana Hatları' Eserinin Müsveddeleri (İstanbul: Akşam Matbaası, n.d. [1934] ), p.5; Dil Yazıları: Türkçenin Etümolojisi [sic] İçin Metot Araştırmaları (İstanbul: Devlet Matbaası, 1934), p.17.

51. Ahmet Cevat [Emre], Dil Yazıları, p.38.

52. Ahmet Cevat [Emre], 'Sumer [sic] Dili İle Bizim Dilimizi Fonetik, Morfoloji, Lûgat ve Nahvî Teşekkül Noktalarından Mukayese', in Birinci Türk Dili Kurultayl: Tezler, Müzakere Zabitlarl (İstanbul: Devlet Matbaas1, 1933), pp.81-94. The official programme of the congress is on p.XXXII.

53. For an earlier, western attempt to compare 'Turanian' and Mesopotamian languages, see François Lenormant, Les Principes de Comparaison de l'Accadien et des Langues Touraniennes: Réponse à une Critique (Paris: Leroux, 1875).

54. Ahmet Cavat [sic] [Emre], Alfabenin Menşei (İstanbul: Marifet Matbaas1, 1933).

55. Ahmet Cevat [Emre], Türkçe ve Hint-Avrupa Dilleri, pp.5-6. Emre's address to the second congress filled an entire issue of Türk Dili. See Ahmet Cevat [Emre], 'Türkçenin HintAvrupa Diliyle Mukayesesi', Türk Dili No:11 (1935).

56. Dr Saim Ali [Dilemre] Bey, 'Türk Filolojisi: Türkçe Bir Hint-Avrupa Dilidir', in Birinci Türk Dili Kurultayl, pp.71-80.

57. Agop Martayan [Dilaçar] Efendi, 'Türk, Sumer [sic], Hint-Avrupa Dilleri Arasındaki Rabitalar', in Birinci Türk Dili Kurultayl, pp.94-104.

58. Mehmet Saffet Bey, 'Türk Dilinin Kıdemi ve Hakimiyeti-Türkçenin Ari Dillerle Münasebeti', in Birinci Türk Dili Kurultayl, pp.110-24; Hakk1 Nezihi Bey, 'Türkçenin Diğer Dillerle Alaka ve Münasebeti - Türkçenin Menşeî Hususiyeti - Hint-Avrupa Ana Lisanı', in Birinci Türk Dili Kurultayl, pp.129-39; Raifpaşazade Fuat [Köseraif] Bey, 'Dillerin Ayrılması', in Birinci Türk Dili Kurultayl, pp.216-32; Abdullah Battal Bey, 'Türk Dili En Eski ve Zengin Dillerden Biridir', in Birinci Türk Dili Kurultayl, pp.232-42.

59. Quoted in Levend, Türk Dilinde Gelişme ve Sadeleșme Evreleri, pp.289-90.

60. 'Samih Rifat [sic] Bey: Resmî Tercümei Hali', Türk Dili No.1 (April 1933), p.43. 
61. Naim Hazım [Onat], 'Büyük Samihi Son Görüşüm', Türk Dili No.1 (April 1933), p.19.

62. İsmail Habib Sevük, the eye-witness, relates that he first heard of the saga from the Minister of Education, Vehbi Bey, who informed him of Samih Rifat's discovery. İsmail Habib Sevük, Dil Davası (İstanbul: İnkilap Kitabevi, 1949), pp.38-9.

63. See Falih Rıfkı [Atay], 'Samih Rıfat', Türk Dili No.1 (April 1933), p.11. Yusuf Akçura, for instance, spoke contemptuously of Samih Rifat's 'famous discovery'. See Yusuf Akçura, Yeni Türk Devletinin Öncüleri, p.25. Yusuf Akçura had to turn about face after 1930 and became one of the chief supporters of the Turkish History and Language Theses.

64. Samih Rıfat, Türkçede Tasrif-i Huruf Kanunlarl ve Tekellümün Menşei: Ankara Maarif Vekaleti Telif ve Tercüme Heyetinde 3 Nisan 1338 Tarihinde Samih Rlfat Bey Tarafindan Okunan Rapor (Ankara: Matbuat ve İstihbarat Matbaas1, 1338).

65. Ibid., p.5.

66. Ibid., pp.42-3.

67. Ibid., p.52.

68. Ibid., p.110. For the monogenesis theory in the Bible, see Genesis 11:1-9.

69. Samih Rıfat, Türkçe'de Tasrif-i Huruf Kanunlarl, p.110.

70. Semavi Eyice, 'Atatürk'ün Büyük Bir Tarih Yazdırma Teşebbüsü: Türk Tarihinin Ana Hatları', Belleten Vol:32 (1968), pp.509-26.

71. Samih Rıfat, 'Türkçe ve Diğer Lisanlar Arasında İrtibatlar', in Birinci Türk Tarih Kongresi: Konferanslar, Münakaşalar (İstanbul: Matbaacılık ve Neşriyat Türk Anonim Şirketi, 1932), pp.52-78.

72. Ruşen Eşref [Ünaydın], Türk Dili Tetkik Cemiyeti: Kurulduğundan İlk Kurultaya Kadar Hatıralar (Ankara: Hakimiyeti Milliye Matbaası, 1933), pp.5-7.

73. Samih Rıfat, 'Türkçenin Âri ve Samî Lisanlarla Mukayesesi', in Birinci Türk Dili Kurultayl: Tezler, Müzakere Zabitları (İstanbul: Devlet Matbaas1, 1933), pp.21-63.

74. A full copy of Atatürk's letter can be found in Türk Dili No:1 (April 1933), pp.2-3.

75. Abdülkadir İnan, Türkoloji Ders Hülasalarl (İstanbul: Devlet Basımevi, 1936), pp.5-6; and Güneş-Dil Teorisi Üzerine Ders Notlart (İstanbul: Devlet Basımevi, 1936), pp.11-12 and $53-4$.

76. From İnan's introduction to N. Marr, Dillerin ve Uluslartn Ayrllmast ve Türk Şivelerinin Ana Vatanı Meselesi Translated with an introduction by Abdülkadir İnan. Etüt No:68, pp.V-VI. Library of the Turkish Language Institute, Ankara.

77. 'Bay Tahsin Ömer'in Tezi: Meksika'da Müstamel Maya Dilindeki Türkçe Kelimeler Hakkında İzahat', Türk Dili, No.12 (1935), pp.89-94.

78. 'Dr S.A. Dilemre'nin Tezi: Eski Dil Mefhumu', Türk Dili, No.12 (1935), pp.73-83.

79. The most comprehensive introduction is Üçüncü Türk Dil Kurultayl 1936: Tezler, Zabitlar (Ankara: Devlet Basımevi, 1937). Also see Etimoloji, Morfoloji ve Fonetik Bakımından Türk Dili (Ankara: Ulus Basımevi, n.d.); H. Reşit Tankut, Güneş-Dil Teorisine Göre Dil Tetkikleri I (İstanbul: Devlet Basımevi, 1936); Abdülkadir İnan, Güneş-Dil Teorisi Üzerine Ders Notlarl. Issues of the official bulletin of the Turkish Language Institute, Türk Dili, between the years 1936 and 1938 are also helpful.

80. H.F. Kvergič, himself, pointed to Carl Gustav Jung's writings on libido and consciousness as a major support for the Sun-Language Theory. See H.F. Kvergič, 'La Güneş-Dil Théorie: Vis á Vis des Théories Linguistiques du Monde', in Üçüncü Türk Dil Kurultayl 1936, pp.439-45; and C.G. Jung, Wandlungen und Symbole der Libido: Beiträge zur Entwicklungsgeschichte des Denkens (Leipzig: F. Deuticke, 1912). In an earlier letter to Kemal Atatürk, which accompanied a precis of his new linguistic theory, Kvergič mentioned 'the Viennese professor Freud', whose principles of psychological analysis constituted the basis of his own study. See, H.F. Kvergič, Türkoloji İncelemesi (Viyana 1935) typescript Turkish translation. Anıtkabir, 1846. The Private Library of Atatürk, Ankara.

81. A concise summary of the Turkish History Thesis can be found in Afet [Afetinan], 'Tarihten Evel ve Tarih Fecrinde', in Birinci Türk Tarih Kongresi, pp.18-41.

82. For instance, Tahsin Mayatepek, Meksiko Şehrile Civarında İki Yerli Kabilenin Güneşe Tazimen Yapdikları Ayine Dair İzahat. Etüt No.56. Unpublished manuscript at the Library of the Turkish Language Institute, Ankara. 
83. Invited scholars were Professor Anagnastopulos, professor of philology at the University of Athens; Dr Bartalini, lecturer in Italian and Latin at the University of Istanbul; Dr A. Bombaci of the University of Napoli; Sir Denison Ross from London; Professor Gabidullin, professor of oriental studies at the University of Moscow; Dr Giese of the Prussian Academy; Father Hilaire de Barenton, a French Sumerologist; Professor Jean Deny, professor at the School of Oriental Languages in Paris; Dr Kvergič, the Viennese philologist; Professor Koji Okubo, director of the Japanese Turkish-Islamic Institute; Professor Meshchaninov, member of the Soviet Academy of Sciences; Dr Miatef from the Royal Library in Sofia; Professor Gyula Nemeth from the University of Budapest; Professor Samoilovich, member of the Soviet Academy of Sciences; Professor Zayançkovski [?] of the University of Warsaw.

84. A list of all members of the commission can be found in Üçüncü Türk Dil Kurultayı 1936, pp.449-51.

85. Professors Anagnastopulos, Deny, and Sir Denison Ross. Ibid., p.482.

86. Ibid., p. 454 .

87. Ibid., pp.460-1.

88. Ibid., p. 465 .

89. Miroslav Hroch, The Social Interpretation of Linguistic Demands in European National Movements, EUI Working Paper EUF No.94/1 (Florence: European University Institute, 1994); Miroslav Hroch, Social Preconditions of National Revival in Europe, trans. Ben Fowkes (New York: Columbia University Press, 2000); Ernest Gellner, Nations and Nationalism (Oxford: Blackwell, 1983). 